\title{
Digital necrosis with squamous cell carcinoma of the tonsil
}

This article was published in the following Dove Press journal:

International Medical Case Reports Journal

27 June 2016

Number of times this article has been viewed

Vinod Warrier'

Ali Ahmad'

Yaqoub Alshatti'

Ali Jafar ${ }^{2}$

'Department of Internal Medicine, Mubarak Al-Kabeer Hospital, Jabriya, Kuwait; ${ }^{2}$ Department of Surgical and Interventional Sciences, University College London, Royal Free Hospital, London, UK
Correspondence: Ali Ahmad Department of Internal Medicine, Mubarak Al-Kabeer Hospital, Jabriya, Kuwait

Email ali_ashkanani5@hotmail.com
Background: Digital necrosis is a rare phenomenon of paraneoplastic syndrome associated with squamous cell carcinoma of the tonsil. Since 1965, more than 70 cases have been reported worldwide in the literature.

Case report: A 54-year-old male smoker presented with Raynaud's phenomenon, proceeding to frank gangrene of the fingers. Working up the case finally pointed toward carcinoma of the tonsil as the underlying cause - a rare paraneoplastic manifestation.

Conclusion: No definite etiology has been found to be the cause of Raynaud's phenomenon in this case of the squamous cell carcinoma of the tonsil. A brief discussion of the literature is also presented.

Keywords: acronecrosis, digital necrosis, paraneoplastic manifestations, Raynaud's phenomenon, squamous cell carcinoma of the tonsil

\section{Case presentation}

A 54-year-old male smoker (20 pack-years) presented with bluish discoloration of the fingers of both hands, associated with pain of 1 month's duration. He also had halitosis at the time of presentation. Examination showed a firm 2-3 cm jugulodigastric node on the right side and an enlarged ulcerated right tonsil. Distal pulses, including the radial and dorsalis pedis, were normal. The patient was not taking any medication, and the family history was unremarkable. Clinically, acrocyanosis was a possibility, and so the causes were searched for. Fine-needle aspiration cytology from the node and a biopsy from the tonsil were arranged. Meanwhile, ischemic symptoms in the hand progressed and developed into frank gangrene and necrosis. By this time the node had increased in size and developed into a fungating growth (Figures 1 and 2).

The diagnostic investigations (ie, laboratory, radiology, etc) have been summarized in Tables 1-6 and Figure 3.

A bronchoscopy was carried out and showed nonspecific inflammatory cells. The biopsy from the tonsil showed squamous cell carcinoma of the spindle cell variety. Fine needle aspiration cytology and the impression smear showed metastasis from the squamous cell carcinoma (Figure 4). Radiological evidence of metastasis in the lungs shown in figure 5 . The present case report was approved by Mubarak Al-Kabeer Hospital ethical board. Verbal informed consent was obtained from the patient for publication of this case report and accompanying images. 


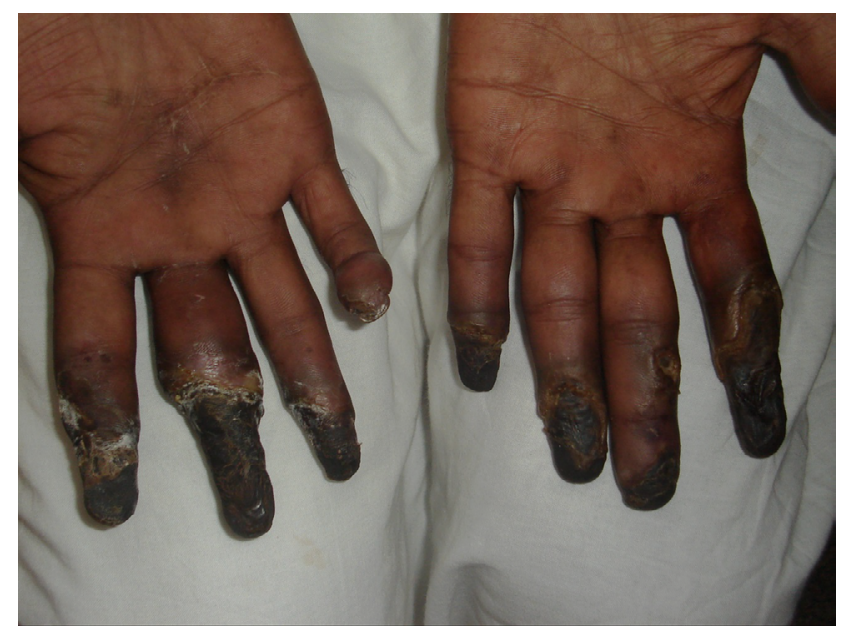

Figure I Gangrenous digits of the patient.

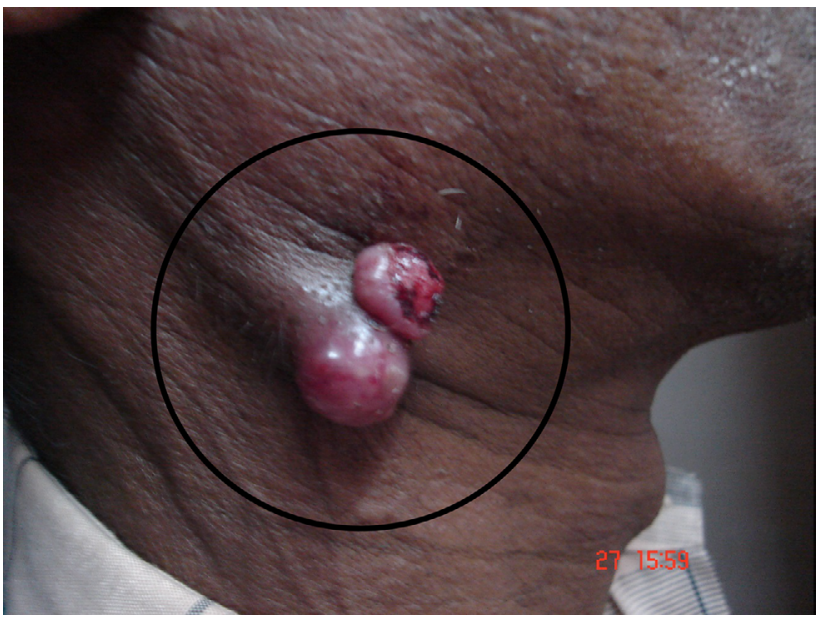

Figure 2 Ulcerated jugulodigastric node.

Table I Routine blood investigations

\begin{tabular}{ll}
\hline Test & Result (normal range) \\
\hline $\begin{array}{l}\text { Complete blood count } \\
\text { Hemoglobin }\end{array}$ & $\mathrm{I} 4.6 \mathrm{~g} / \mathrm{dL}(13.5-17.5 \mathrm{~g} / \mathrm{dL})$ \\
Total white blood cell count & 18,600 cells/ $\mu \mathrm{L}(3,500-10,500$ cells/ \\
& $\mu \mathrm{L})$ \\
Differential count & Neutrophils $77 \%(40 \%-80 \%)$ \\
Platelets & Lymphocytes $19 \%(20 \%-40 \%)$ \\
Erythrocyte sedimentation rate & $\begin{array}{l}\text { Eosinophils } 4 \%(1 \%-6 \%) \\
230,000 \mu \mathrm{L}(150,000-450,000 / \mu \mathrm{L})\end{array}$ \\
& $80 \mathrm{~mm} / \mathrm{h}(<20 \mathrm{~mm} / \mathrm{h})$ \\
Liver function test & Within normal range \\
Renal function test & Within normal range \\
\hline
\end{tabular}

Table 2 Immunology screening

\begin{tabular}{ll}
\hline Test & Result \\
\hline Antinuclear antibody & Negative \\
Rheumatoid factor & Negative \\
P-ANCA & Negative \\
C-ANCA & Negative \\
Antiphospholipid antibodies & \\
Anticardiolipin antibodies & Negative \\
Anti- $\beta_{2}$ glycoprotein & Negative \\
Lupus anticoagulant & Negative \\
Complements & \\
C3 & Normal \\
C4 & Normal \\
\hline Abbreviations: P-ANCA, perinuclear anti-neutrophil cytoplasmic antibody; \\
C-ANCA, cytoplasmic anti-neutrophil cytoplasmic antibody. \\
\hline
\end{tabular}

Table 3 Immunoglobulin screening

\begin{tabular}{ll}
\hline Test & Result \\
\hline Immunoglobulin A, G & Normal \\
Cryoglobulin & Negative \\
\hline
\end{tabular}

Table 4 Virology screening

\begin{tabular}{ll}
\hline Test & Result \\
\hline $\mathrm{HBsAg}$ & Negative \\
Anti-HCV antibodies & Negative \\
HIV & Negative \\
\hline
\end{tabular}

Abbreviations: $\mathrm{HbsAg}$, hepatitis b surface antigen; $\mathrm{HCV}$, hepatitis $\mathrm{C}$ virus; $\mathrm{HIV}$, human immunodeficiency virus.

Table 5 Other tests

\begin{tabular}{ll}
\hline Test & Result \\
\hline Thyroid profile & Normal \\
Mantoux test & Negative \\
\hline
\end{tabular}

Table 6 Imaging studies

\begin{tabular}{ll}
\hline Imaging modality & Result \\
\hline Chest X-ray & Right lower zone consolidation \\
Doppler study of the upper limb & Normal \\
\hline
\end{tabular}

\section{Discussion}

Acronecrosis is a rare manifestation of malignant neoplasms such as neoplasm of the gastrointestinal tract, lung, and breast; ovarian and uterine carcinomas; renal adenocarcinoma; multiple myeloma; leukemia; and Hodgkin lymphoma, with the underlying mechanism still not being fully understood. ${ }^{1-4}$ The clinical presentation can range from splinter hemorrhages with pulp atrophy to digital necrosis. Raynaud's syndrome is unlikely in our patient, because the presentation was rapidly progressive over a short period of time and with no aggravating factors. Raynaud's syndrome, however, has been reported as an initial manifestation of an ovarian 
History

1) History compatible with Raynaud's

a. Sensitivity to cold

b. Changing color of the fingers when exposed to cold weather

c. Turning blue or white or both when cold

2) Severity and frequency of the episodes

3) Smoking history

4) Systemic review to eliminate secondary causes; these include rash, morning stiffness, arthritis, photosensitivity alopecia, dry eyes/ dry mouth, tightness of the skin, puffiness of the fingers, gastric acid regurgitation, dysphagia

5) Family history of Raynaud's and connective tissue disease

6) Rule out potential causative agents such as drugs and toxins (chemotherapy agents, interferon, nicotine, narcotics, cyclosporine, hypothenar hammer syndrome), or neuropathy (carpal tunnel syndrome)

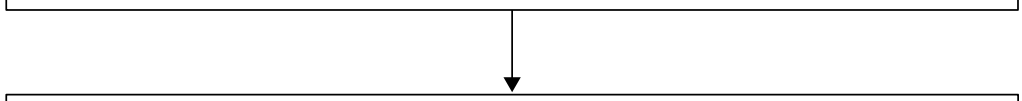

Physical examination

1) Rheumatological and musculoskeletal examination (looking for signs of connective tissue disease)

2) Other systematic physical examination

If unremarkable medical history and examination, there is no need for further workup and primary Raynaud's phenomenon can be considered

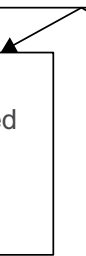

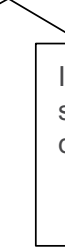

If positive symptoms and signs suggestive of connective tissue disease, then further investigations to be carried out

\begin{tabular}{l}
\hline Investigations: \\
Complete blood count \\
Erythrocyte sedimentation rate \\
Renal function test and urinalysis \\
Antinuclear antibodies \\
Disease-specific auto-antibodies \\
Rheumatoid factor \\
C3 and C4 complement level \\
Thyroid-function test \\
Serum protein electrophoresis \\
Cryoglobulins
\end{tabular}

If there is any history of asymmetrical attacks, absent pulse, or evidence of ischemia, arterial Doppler ultrasonography or angiography should be performed to rule out atherosclerosis or emboli disease.
Differential diagnosis of secondary Raynaud's

Scleroderma

Systemic lupus erythematosus

Mixed connective-tissue disease

Dermatomyositis

Polymyositis

Sjogren's syndrome

Hypothyroidism

Cancer

Cold agglutinin syndrome

POEMS* syndrome

Cryoglobulinemia

Cryofibrinogenemia

Figure 3 Diagnostic flowchart for Raynaud's Phenomenon.

Notes: * Refers to polyneuropathy, organomegaly, endocrinopathy, monoclonal gammopathy, and Skin changes. It is a rare multisystemic disease that occurs in the setting of a plasma cell dyscrasia.

carcinoma. ${ }^{5}$ Over the last 45 years, more than 70 cases $^{6}$ have been reported in the medical literature worldwide, describing the association of digital necrosis with different types of malignant neoplasms. ${ }^{7}$

The suggested possible underlying mechanisms of the digital ischemia include arterial vasospasm mediated by immune complexes, blood hypercoagulability secondary to vascular occlusions, cryoglobulinemia, and necrotizing vasculitis. In our patient, cryoglobulins and immune complexes were not detected, and the thrombophilia screen was negative. Since the Doppler study of the hand was normal, there was unlikely to be a significant proximal (large) vessel component. 

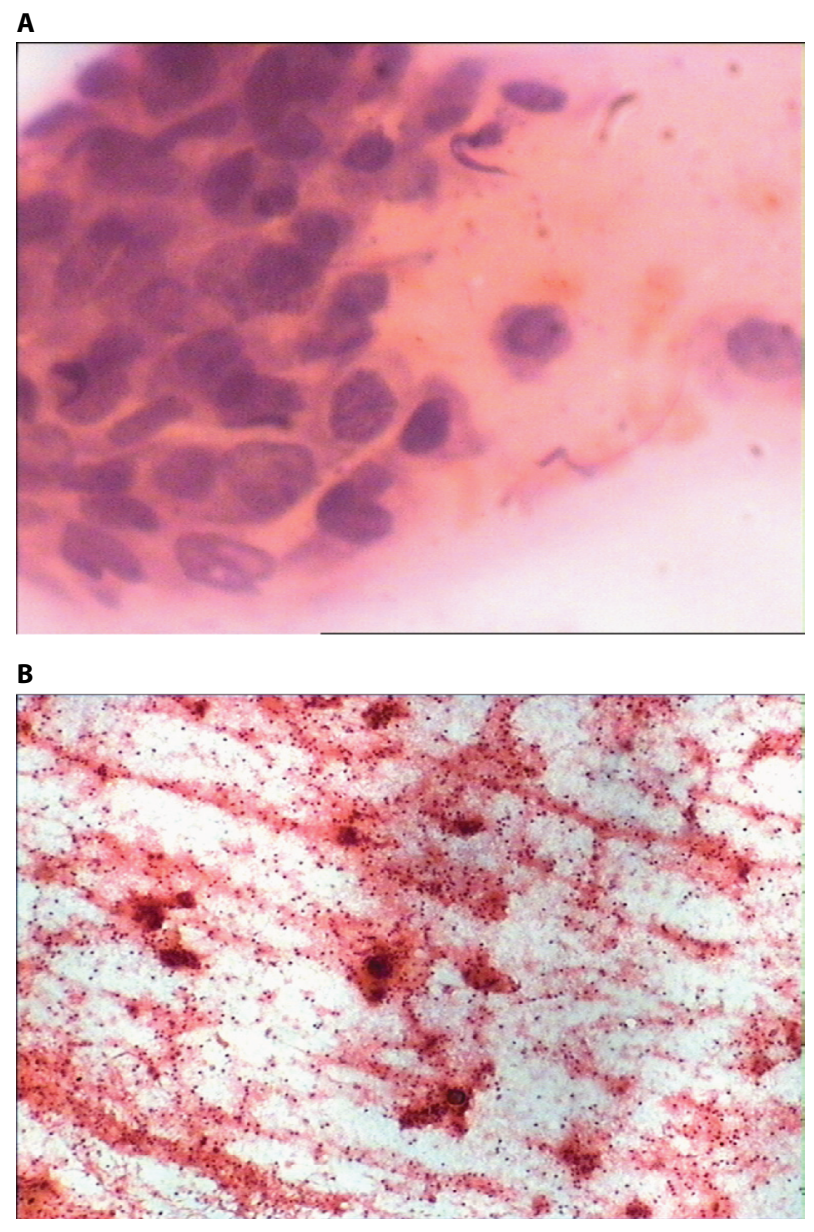

Figure 4 Histological specimen of jugulodigastric lymph node

Notes: (A) Biopsy from the ulcerated jugulodigastric node showing spindle cell carcinoma. (B) Cytology smear from the ulcerated jugulodigastric node showing spindle cell carcinoma.

There is one reported case of digital necrosis resulting from squamous cell carcinoma of the tonsil in $2002 ;{ }^{8}$ therefore, it could be inferred that squamous cell carcinoma of the upper aerodigestive tract could be associated with acronecrosis.

The size of the primary tumor reduced following radiotherapy. The radiotherapy regimen given to the patient included intensity-modulated radiotherapy and weekly cisplatin $\left(50 \mathrm{mg} / \mathrm{m}^{2}\right)$. The hand function failed to show any improvement, and the patient eventually succumbed to the advanced disease.

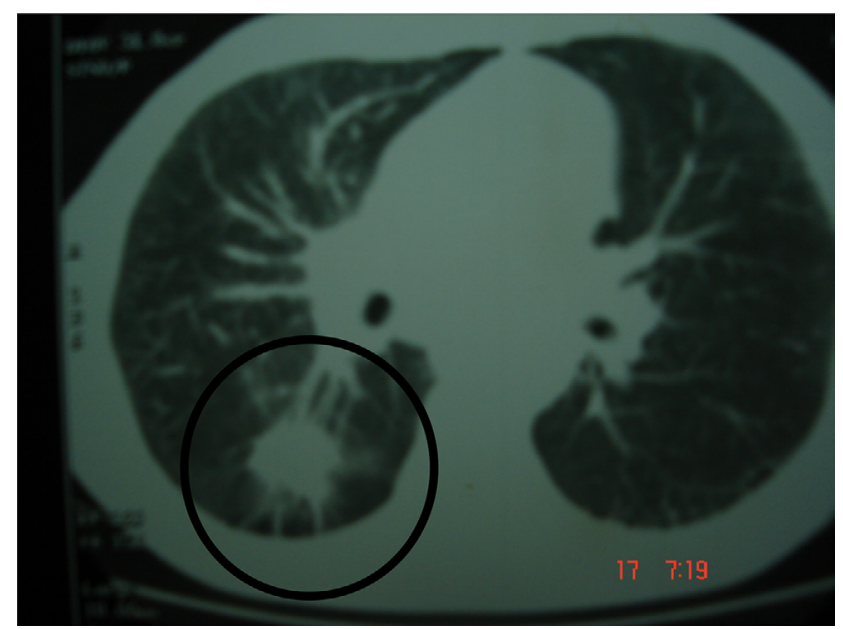

Figure 5 Lymphangitis carcinomatosis involving the right lobe and mediastinal adenopathy.

\section{Conclusion}

To date, acronecrosis as a paraneoplastic manifestation has been rarely reported. We report this case so as to highlight the association of acronecrosis as a paraneoplastic manifestation of a squamous cell carcinoma of the tonsil.

\section{Disclosure}

The authors report no conflicts of interest in this work.

\section{References}

1. Petrie M, Fye H. Digital necrosis: a paraneoplastic syndrome. J Rheumatol. 1985;12:800-802.

2. Taillan B, Castanet J, Garnier G, et al. Paraneoplastic Raynaud's phenomenon. Clin Rheumatol. 1993;12(2):281-282.

3. Iamandi C, Dietemann A, Grosshans E, Pauli G, Quoix E. Paraneoplastic digital necrosis in a patient with small-cell lung cancer. J Clin Oncol. 2002;20(23):4600-4601.

4. Chow SF, McKenna CH. Ovarian cancer and gangrene of the digits: case report and review of the literature. Mayo Clin Proc. 1996;71(3): 253-258.

5. Kohli M, Bennett RM. Raynaud's phenomenon as a presenting sign of ovarian adenocarcinoma. J Rheumatol. 1995;22:1393-1394.

6. Wigley FM, Herrick A, Flavahan N, eds. Raynaud's Phenomenon -A Guide to Pathogenesis and Treatment. New York, NY: Springer Science + Business Media, LLC; 2015:141-162.

7. Hawley PR, Johnston AW, Rankin, JT. Association between digital ischemia and malignant diseases. Br Med J. 1967;22(3):208-212.

8. Wright JR, Gudelis S. Digital necrosis associated with squamous cell carcinoma of the tonsil. Head Neck. 2002;24(11):1019-1021.

\section{Publish your work in this journal}

The International Medical Case Reports Journal is an international, peer-reviewed open-access journal publishing original case reports from all medical specialties. Previously unpublished medical posters are also accepted relating to any area of clinical or preclinical science. Submissions should not normally exceed 2,000 words or pages including figures, diagrams and references. The manuscript management system is completely online and includes a very quick and fair peer-review system, which is all easy to use. Visit http://www.dovepress.com/testimonials.php to read real quotes from published authors.

Submit your manuscript here: https://www.dovepress.com/international-medical-case-reports-journal-journal 